\title{
Perak Malay Hard Landscape Elements: An overview
}

\author{
Ahmad Zamil Zakaria, Mohd Sabrizaa Abd Rashid, Syazwani Ahmad \\ Faculty of Architecture, Planning \& Surveying, \\ Universiti Teknologi MARA, \\ Seri Iskandar Campus, 32610 Perak, Malaysia \\ zamil227@perak.uitm.edu.my
}

\begin{abstract}
This study is a continuation of previous studies about the Malay landscape in the state of Perak. The purpose of this study was to obtain a list of hard landscape elements that exist in the residential compound of the Malays in the present. The objective of the study was to determine the function of each component of a hard landscape. The scope of the survey is along the Perak River in Perak Tengah District. The need for this study is to reveal the identity of the Malay landscape and improve the selfesteem of the community indirectly.
\end{abstract}

Keywords: Perak Malay garden; Malay landscape; Malay garden concept; Cultural Landscape

eISSN 2398-4279 @ 2018. The Authors. Published for AMER ABRA cE-Bs by e-International Publishing House, Ltd., UK. This is an open access article under the CC BY-NC-ND license (http://creativecommons.org/licenses/bync-nd/4.0/). Peer-review under responsibility of AMER (Association of Malaysian Environment-Behaviour Researchers), ABRA (Association of Behavioural Researchers on Asians) and cE-Bs (Centre for EnvironmentBehaviour Studies), Faculty of Architecture, Planning \& Surveying, Universiti Teknologi MARA, Malaysia.

DOI: https://doi.org/10.21834/ajqol.v3i10.105 


\subsection{Introduction}

The history of Perak has shown us, how the Malay race was so fond of their people (Abdul Halim Nasir, 2007). According to Zamil et al., (2014), one of the reasons why the concept of Malay landscape cannot be emphasized is because the community has a strong sense of inferiority. Traditional Malay people develop their garden to attain synchronization with the environment that is the concept, activities and function of the house interior is tolerant toward the external spaces (Yuan, 1991). Based on the cultural context, researchers have been searching for hard landscape elements in the Perak Malay culture.

\section{Problems Statement}

At present, the characteristics and the identity of the hard landscape of Perak Malay have not highlighted while it is an art and a way of life which has inherited a long time ago.

\section{Research Objective}

The objective of this study was to identify elements of the hard landscape, which mentioned in the old Malay manuscripts. Besides, it is also to determine the elements of the hard landscape with its function in the present.

\section{The Scope of the Study}

The extent of this study covers traditional houses Perak Malay, along the Perak River in Perak Tengah district. The Kutai house is among the important criteria in the selection of the sample because it classified as the types of the oldest traditional Malay houses in the district of Perak Tengah.

\subsection{Literature Review}

This literature review has focused on the existing design, selection of research methods, introduction to the subject of study, and also the importance of the old manuscripts in this study.

\section{Design Concept}

According to Mitchell (2002), the cultural landscape is a medium that can be used to identify and understand a particular race. The implicit character is the main difference between the approaches of traditional Malaysian society with Western society in the aspect of design, including the environmental design (Abdul Hadi \& Julaihi, 2010).

\section{The cultural landscape}

According to Melnick (1994), it is hard to identify the values and resources of the cultural landscape because it lost through rapid development and global climate change. Referring to Haza \& Ramzi (2014), the cultural landscape, on the other hand, is described as human activities on land and past experiences. 


\section{Malay Traditional House}

According to Ariffin \& Talib (2005), in Perak, they have the old traditional houses dubbed Kutai House. Development of technology and modernization, construction of a traditional Malay house had been forgotten and the existing house already unoccupied again on the determinants of mortality and migration.

\section{Hard Landscape}

The hard landscape is an essential element in any landscape design. Highlighting the soft landscape in the garden is necessary. There was a study conducted by researchers from Universiti Teknologi Malaysia in 2006 and found that the Malay resident compound contains eight (8) elements as shown in the table below.

Table 1: The list of landscape furniture recorded by the past researchers.

\begin{tabular}{|c|c|c|c|}
\hline No. & $\begin{array}{c}\text { Local Name } \\
\text { (As be called by local } \\
\text { people) }\end{array}$ & English Name & $\begin{array}{l}\text { The placement of hard } \\
\text { landscape. }\end{array}$ \\
\hline 1. & Tempayan & Water vessel & Side yard \\
\hline 2. & Guri & Guri & Backyard \\
\hline 3. & Pasu Bunga & Flower Pot & $\begin{array}{c}\text { Front yard } \\
\text { Side yard }\end{array}$ \\
\hline 4. & Pangkin & Resting hut & Side yard \\
\hline 5. & Perigi & Well & Backyard \\
\hline 6. & Perun & Dump site & $\begin{array}{l}\text { Side yard } \\
\text { Backyard }\end{array}$ \\
\hline 7. & Reban & Hen Coop & Backyard \\
\hline 8. & Jelapang / Kepok Padi & Paddy store & Side yard \\
\hline
\end{tabular}

Source: Abdullah Sani Ahmad, et al., (2006)

\section{Old Malay Manuscripts}

According to Abdul Hadi \& Julaihi (1994), there are three main categories of myth in Malay culture, namely the Salasilah, Hikayat, and Seloka. Old Malay manuscripts mention hard landscape elements such as we meet today. It has been proven that the hard landscape elements have long been used and passed on to their heirs.

Table 2: The list of landscape furniture recorded in the old manuscripts.

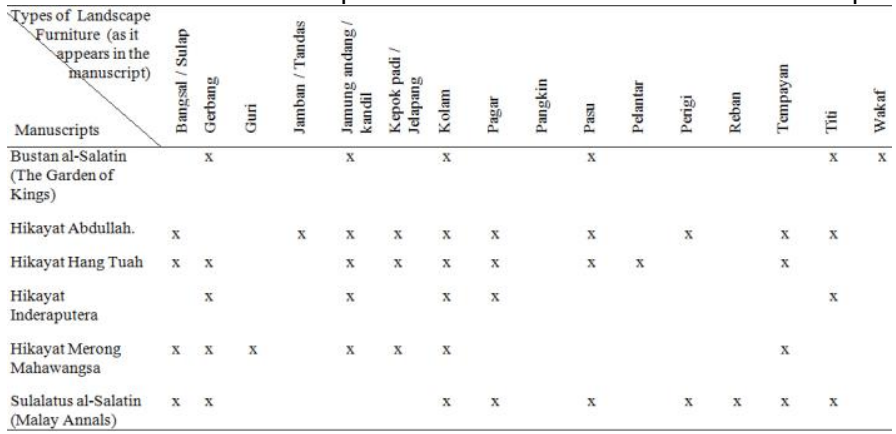

Source: Zamil et al., (2013) 
The table above shows that the old Malay manuscripts recorded the use of hard landscape elements over the years. The researchers have compared what has been recorded in the manuscript with the elements that are found while conducting site visits.

\subsection{Methodology}

The method of this research is through observation, conducting surveys and get referrals from sources related to the Malay race and locals. According to Hasandi (2010), in the Perak Tengah District, there are 23 Kutai houses ever recorded in his research. Numbers of houses sampled in this study are 17 units ( $36 \%$ of the population). The observation method using to watch something carefully and accurately record in some way the activities or situation to capture data relevant to the research issues (Gray \& Malins, 2004).

\section{Sample Criteria}

The sample is selected according to the criteria as follows:

1) Traditional Malay Village

2) The Malays houses that still maintain the values of authenticity

3) The Kutai house

4) The hard and soft landscape elements existed

5) The compound distribution - has a large yard

6) No resident or still inhabited

\section{Assessing the Cultural Landscape}

This study has used the Melnick's method, which states the importance to identify the characteristics and elements of nature, culture, and visual interest. This process facilitates the researchers, for more focus on obtaining the necessary data.

\section{Assessing the Malay Landscape}

The researchers have used the semi-structured in-depth in the interview session to obtain intangible data. According to Gray \& Malins (2004), the interview technique is the best way of finding out the person values, preference, attitudes, beliefs, and feeling.

\subsection{Findings and Discussions}

Researchers can detect the elements and layout of hard landscape significantly in all houses visited. The table below shows a list of the hard landscape that found with its functions.

Table 3: Landscape furniture found during the site visit.

\begin{tabular}{lll}
\hline No. & Local Name & The function of each element of hard landscape \\
\hline 1 & Barn & $\begin{array}{l}\text { The barn is a walled thatched building. It is also } \\
\text { possible without high walls and floors. }\end{array}$ \\
2 & Flower pot & $\begin{array}{l}\text { Flower pots have been used down the ages yet to be } \\
\text { placed in the courtyard. }\end{array}$
\end{tabular}


$3 \quad$ Water vessel

$4 \quad$ Water feature

$5 \quad$ Resting hut

$6 \quad$ Bathroom

$7 \quad$ Dump site

$8 \quad$ Latrine

$9 \quad$ Coop

$10 \quad$ Guri

$11 \quad$ Well

12 Suspension

13 Bench
For the Malay community, water vessel usually made without carving and used for storing water and fermenting foods.

The place to store water, which was built next to the stairs.

Resting hut is a four-legged wooden building or more (depending on a size) and slightly lower than the table. Bathrooms need to be built outside the house with the toilet.

Perun is a hole dug, the location is in the back of the Malay house, and be a place to dump and burn rubbish.

A simple toilet such as a hole in the ground. A latrine is a mere waste collector.

Coop is hard landscape elements, which can be found in traditional Malay houses around a courtyard.

Guri or pitcher has the same characteristics as a water vessel, but different from the size and smaller opening mouth.

Wells is a hole dug to obtain water resources (groundwater).

It is a place to hang washed clothes.

Seating in the yard which intended for leisure activities.

Source: Author, Site visit and Zamil et al., (2015)

The table above shows the Perak Malay community still maintains hard landscape elements in their residential compound. The uses of hard landscape elements had a bit different with the utilization of the Malay community in the past.

Table 4: The site visit discovery.

\begin{tabular}{|c|c|c|c|c|c|c|c|}
\hline \multirow[b]{2}{*}{ No } & \multirow[b]{2}{*}{ Conditions } & \multicolumn{6}{|c|}{ Condition level: (frequency and percentage) } \\
\hline & & Very Poor & Poor & Average & Good & $\begin{array}{l}\text { Very } \\
\text { Good } \\
\end{array}$ & $\begin{array}{c}\text { Total } \\
\text { Number }(\mathrm{n})\end{array}$ \\
\hline \multicolumn{8}{|c|}{ 1) Sample of Criteria } \\
\hline 1 & Traditional Malay Village & $\begin{array}{c}2 \\
(11.76 \%) \\
\end{array}$ & $\begin{array}{c}4 \\
(23.53 \%) \\
\end{array}$ & $\begin{array}{c}5 \\
(29.41 \%) \\
\end{array}$ & $\begin{array}{c}5 \\
(29.41 \%) \\
\end{array}$ & $\begin{array}{c}1 \\
(5.88 \%) \\
\end{array}$ & 17 \\
\hline 2 & $\begin{array}{l}\text { The Malays houses that still } \\
\text { maintain the values of authenticity }\end{array}$ & $\begin{array}{c}3 \\
(17.65 \%)\end{array}$ & $\begin{array}{c}3 \\
(17.65 \%)\end{array}$ & $\begin{array}{c}4 \\
(23.53 \%)\end{array}$ & $\begin{array}{c}5 \\
(29.41 \%)\end{array}$ & $\begin{array}{l}2 \\
(11.76 \%)\end{array}$ & 17 \\
\hline 3 & KUTAI House & $\begin{array}{c}2 \\
(11.76 \%) \\
\end{array}$ & $\begin{array}{c}4 \\
(23.53 \%) \\
\end{array}$ & $\begin{array}{c}4 \\
(23.53 \%) \\
\end{array}$ & $\begin{array}{c}5 \\
(29.41 \%) \\
\end{array}$ & $\begin{array}{c}2 \\
(11.76 \%) \\
\end{array}$ & 17 \\
\hline 4 & $\begin{array}{l}\text { The hard and soft landscape } \\
\text { elements existed }\end{array}$ & $\begin{array}{c}4 \\
(23.53 \%)\end{array}$ & $\begin{array}{c}2 \\
(11.76 \%)\end{array}$ & $\begin{array}{c}3 \\
(17.65 \%)\end{array}$ & $\begin{array}{c}7 \\
(41.18 \%)\end{array}$ & $\begin{array}{c}1 \\
(5.88 \%)\end{array}$ & 17 \\
\hline 5 & $\begin{array}{l}\text { The compound distribution- has a } \\
\text { large yard }\end{array}$ & $\begin{array}{c}3 \\
(17.65 \%) \\
\end{array}$ & $\begin{array}{c}2 \\
(11.76 \%)\end{array}$ & $\begin{array}{c}4 \\
(23.53 \%) \\
\end{array}$ & $\begin{array}{c}5 \\
(29.41 \%) \\
\end{array}$ & $\begin{array}{c}3 \\
(17.65 \%) \\
\end{array}$ & 17 \\
\hline 6 & No resident and Still inhabited & $\begin{array}{c}2 \\
(11.76 \%) \\
\end{array}$ & $\begin{array}{c}4 \\
(23.53 \%) \\
\end{array}$ & $\begin{array}{c}4 \\
(23.53 \%) \\
\end{array}$ & $\begin{array}{c}5 \\
(29.41 \%) \\
\end{array}$ & $\begin{array}{c}2 \\
(11.76 \%) \\
\end{array}$ & 17 \\
\hline \multicolumn{8}{|c|}{ 2) Landscape Furniture Arrangement } \\
\hline 1 & No formallayout & $\begin{array}{c}2 \\
(11.76 \%)\end{array}$ & $\begin{array}{c}3 \\
(17.65 \%) \\
\end{array}$ & $\begin{array}{c}5 \\
(29.41 \%) \\
\end{array}$ & $\begin{array}{c}5 \\
(29.41 \%) \\
\end{array}$ & $\begin{array}{c}2 \\
(11.76 \%)\end{array}$ & 17 \\
\hline 2 & Traditional features & $\begin{array}{c}2 \\
(11.76 \%)\end{array}$ & $\begin{array}{c}4 \\
(23.53 \%) \\
\end{array}$ & $\begin{array}{c}4 \\
(23.53 \%) \\
\end{array}$ & $\begin{array}{c}5 \\
(29.41 \%) \\
\end{array}$ & $\begin{array}{c}2 \\
(11.76 \%)\end{array}$ & 17 \\
\hline 3 & Based on the philosophy & $\begin{array}{c}2 \\
(11.76 \%)\end{array}$ & $\begin{array}{c}3 \\
(17.65 \%)\end{array}$ & $\begin{array}{c}6 \\
(35.29 \%)\end{array}$ & $\begin{array}{c}3 \\
(17.65 \%)\end{array}$ & $\begin{array}{c}3 \\
(17.65 \%)\end{array}$ & 17 \\
\hline
\end{tabular}

Source: Author, Site visit, (2015)

For the first part is the "Sample of Criteria", there are six (6) criteria were reviewed to determine the physical condition of the sample studied.

The first (1) criteria are the Traditional Malay Village, researchers have found that $35.3 \%(n=6)$ were obtained in a good condition due to the village environment that still 
maintains cleanliness around their homes. It represents $35.3 \%(n=6)$ samples in less favorable due to an uninhabited dwelling.

The second (2) criteria are Malay houses that still maintain the values of authenticity or originality. Majority score was $41.2 \%(n=7)$ in good condition to maintain the original appearance of the Malay house. While $35.3 \%(n=6)$ in a bad condition due to the renovation of the house leading to the authenticity of the architecture of the house were affected, and the maintenance of an abandoned house has resulted in some parts of the house had collapsed.

The third (3) criteria are, the sample for this study must be consisting of Kutai house. The findings majority score of $41.2 \%(n=7)$ is a house in good condition, due to the still inhabited and well-kept. While $35.3 \%(n=6)$ of the Kutai house in a bad condition, it is caused by uninhabited and inadequate care by the owner of the house.

The fourth (4) criteria are elements of hard and soft landscape in the surrounding of the sample studied. The findings revealed that $47.1 \%(n=8)$ elements of hard and soft landscape in a good condition. While $35.3 \%(n=6)$ elements of hard and soft landscaping in a poor condition.

The fifth (5) criteria are the selection of a sample must have a large yard. Majority score was $47.1 \%(n=8)$ sets the house in an excellent condition of the planting, maintenance, and arrangement of elements per the needs of the owner. While $29.4 \%(n=5)$ compound house in a bad condition. An uninhabited house causes it, and this has resulted in the plant grows wild around the residential compound.

The sixth (6) criteria still inhabit the house and not occupied. The study found that majority score of $41.2 \%(n=7)$ housing in good condition. The findings, which houses inhabited and uninhabited but managed by neighbors, have a substantial impact on the house because it will be more manageable and clean. Whereas $35.3 \%(n=6)$ of the house in a poor condition as a result of the house has been uninhabited too long, this has led to a bush and saw an unkempt yard.

\section{Site Visit Observation}

17 houses compound has been studied, and site selection study was performed using "Simple Random Sampling". The results of the observations found; most of the hard landscape elements are not well managed. Besides, there is a little problem in the interview process caused by the homeowner no longer lives at home or have died or were handed over to their heirs.

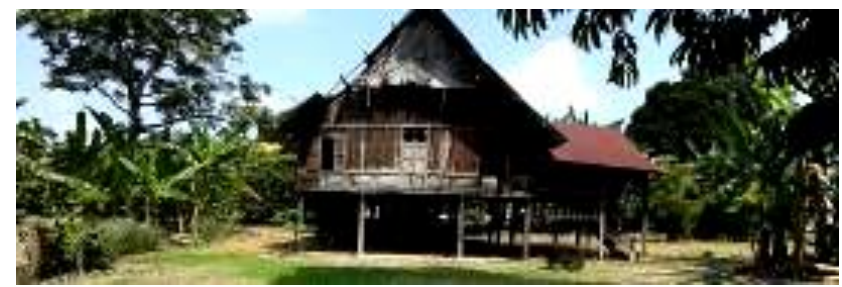

(a) 


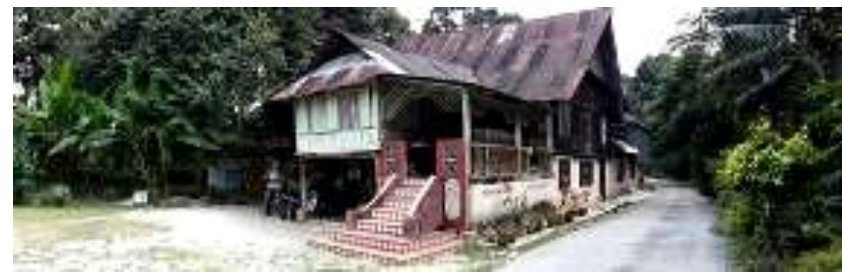

(b)

Fig. 1. $(a-b)$ Shows Kutai house compound at Bota Kanan that are selected to become a sample in this study.

(Sources: Author, Site visit, 2015)

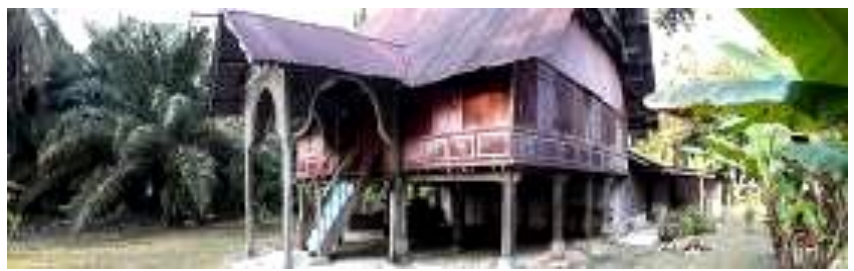

(c)

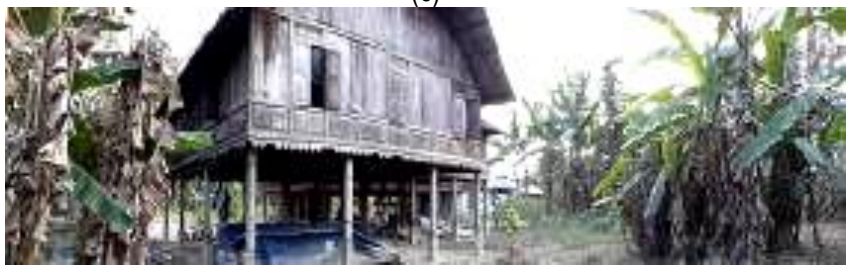

(d)

Figure 2: $(c-d)$ Shows Kutai house compound at Kampung Gajah that are chosen to become a sample in this study.

(Sources: Author, Site visit, 2015)

\section{The landscape furniture arrangement}

All of these traditional houses have a spacious courtyard. From these studies, we can see that the community that inhabits traditional house along the Perak River is less sensitive to the landscape around the house. The layout of hard landscape views unattractive, disorganized and messy. The design of the hard landscape seen scattered and the arrangement is, according to the needs of the homeowner.

The second part of the study is Landscape Furniture Arrangement (refer to Table 4), which is divided into three issues. It is to get the actual physical condition of the sample being studied and its impact on the placement of hard landscape elements in the residential compound.

The first (1) factor is no formal layout. The results of the majority of scores were obtained that $41.2 \%(n=7)$ in good condition while $29.4 \%(n=5)$ in a bad situation. It can be concluded 
that the placement of a hard or soft landscape is depending on the needs of the owner in his daily activities and may indirectly help to utilization and care of the existing landscape.

The second (2) factors are the traditional features that are maintained at present. In the context of traditional features, things that should be emphasized is the practice of bygone community which is still practiced by the community at the moment; as an example the placement of guri or jars in front of the house as a means of washing the feet before entering the house. Majority score was $41.2 \%(n=7)$ showed that the landscape furniture in good condition and there are still around the house. While $35.3 \%(n=6)$ showed a landscape furniture in a poor condition due to no longer, use nowadays.

The third (3) factor is based on the philosophy of the community about the placement of hard landscape elements. Majority scores obtained is $35.3 \%(n=6)$ which follows the right philosophy, and $29.4 \%(n=5)$ were not following the philosophy of the old Malay community.

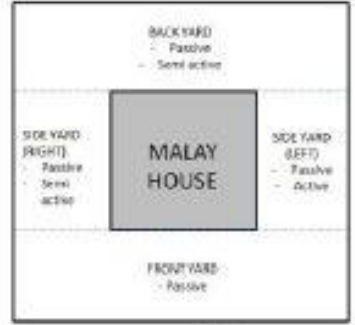

(a)

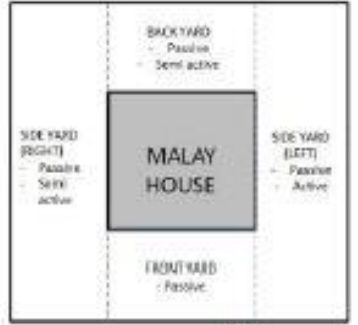

(b)

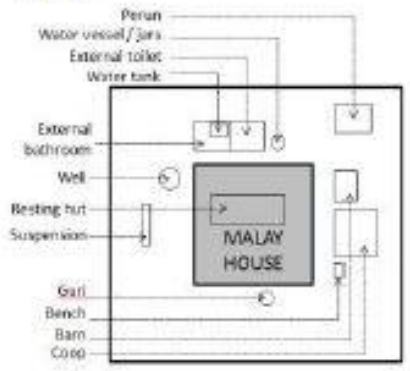

(c)

Figure 3: Common Model 1(a) \& 2 (b) The placements of landscape furniture based on its function on a different compound. (c) The general model of the hard landscape of the Malay house compound.

(Sources: Author, Site visit, 2015)

\section{Materials}

The materials used to make hard landscape here are not seen much differently from making hard landscape elsewhere. For example, water vessel, guri and flower pots made of clay or ceramic. From the standpoint of materials, the researchers did not have any problem to recognize because it looks typical. 


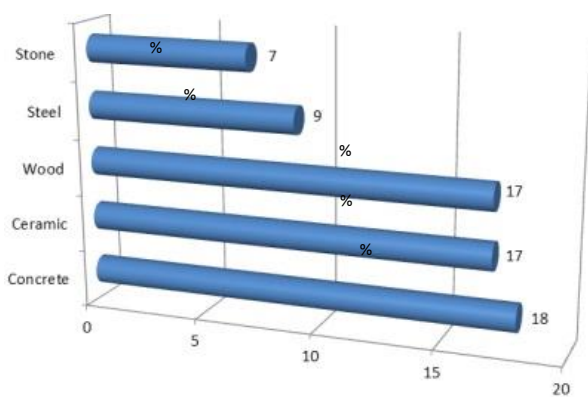

Figure 4: The landscape furniture materials.

(Sources: Author, 2015)

According to the above chart, the concrete material has the highest percentage with a frequency of $27 \%(n=18)$, followed by ceramic material and wood material with each frequency by $25 \%(n=17)$. The use of concrete material that much nowadays is to replace the wood material which is more convenient to maintain the hard landscape elements.

\section{Condition of the Hard Landscape}

Most of the hard landscape elements that found in the selected houses are not in good condition. It occurs when items such as the water vessel, guri, toilets and bathrooms outside the house no longer used at present.

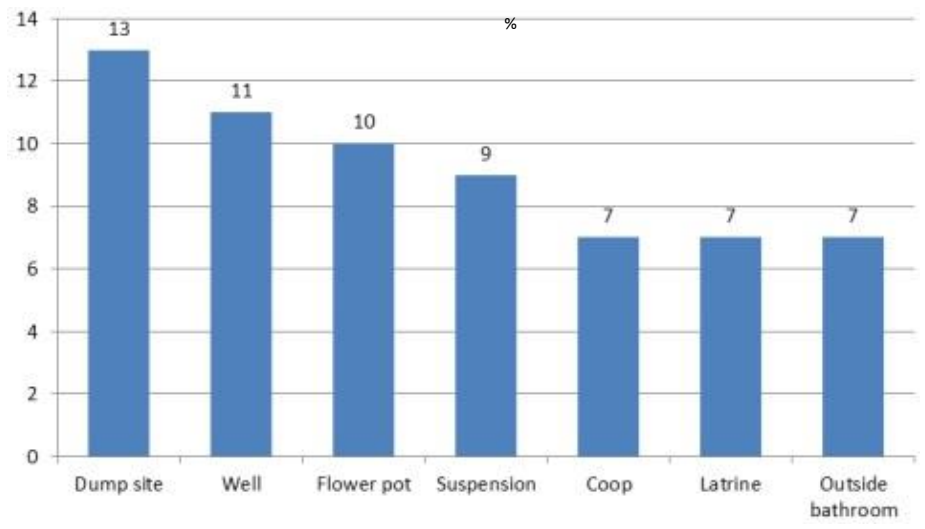

Figure 5: The types of landscape furniture.

(Sources: Author, 2015)

According to the above chart, the highest percentage of wood with a frequency of $20 \%$ $(n=13)$ followed by a well with $17 \%(n=11)$. The lesser is the chicken coop, outdoor toilets and outside bathrooms each obtaining frequency of $11 \%(n=7)$. 
Perception is the interpretation of what is in his senses or felt by the individual. This process happens so that people are aware of the things in their environment through their senses. Below is a list of complications to be solved to create the concept and identity of the Perak Malay landscape.

1) Hard landscape layout

The current design is not organized and neat, although it has been prepared according to the needs of the homeowner.

2) Maintenance of hard landscape

The maintenance issue is critical because hard landscape elements that damaged will disfigure the landscape around the house.

3) Keep the house compound clean

The clean home environment will demonstrate the use of Islamic philosophy, which wants each follower to maintain cleanliness wherever they go.

4) Realize the philosophy of the old Malays

The Malay community at present is less exposed to the view of the old Malay community. Most of the houses visited no longer use hard landscape elements as told by the previous generation.

5) Learn the history of the Malay race

It is to create a strong identity of the Malay race nowadays.

6) Cooperation with Local Authorities and State Governments

The Malay community must work together with local authorities and the state government to highlight the cultural life of the Malay in Perak.

\subsection{Conclusion}

Through this study, researchers were able to identify the strengths and weaknesses inherent in the Perak Malay landscape. There are strength needs to be highlighted to create a new identity of the Perak Malay landscape. The weaknesses in the Perak Malay landscape must be tackled; to enable the new identity of the Perak Malay landscape introduced to the public. Also, this study is the 'benchmark' for research to be carried out in other districts after this.

\section{Acknowledgement}

We would like to express our gratitude to the Research Management Center (RMC), Universiti Teknologi MARA, for granting full trust on us to do this research. Special thanks to our sponsors of MOE - Fundamental Research Grant Scheme (FRGS) for providing an adequate provision for this project. Thanks also to the Centre for Knowledge and Understanding of Tropical Architecture and Interior (KUTAI) and Taman Alam Melayu Nusantara (T.A.M.A.N) UiTM Perak for the invaluable support during the research period. 


\section{References}

Abdul Hadi Harman Shah, Julaihi Wahid (2010). Konsepsualisasi Ruang dan Habitat Tradisional Melayu, Sari International Journal of the Malay World and Civilisation 28(1) Pages 177-187.

Abdul Halim Nasir (2007). Lembangan Sungai Dalam Peradaban Melayu, Penerbit UKM, Malaysia.

Ahmad Zamil Zakaria, Ismail Hafiz Salleh, Mohd Sabrizaa Abdul Rashid (2013). Landscape Furniture Present In The Ancient Malay Garden According To Old Manuscripts And Their Effects On The Formation Of Malay Garden Design Concept Model In Malaysia, Procedia - Social and Behavioral Sciences, Procedia - Social and Behavioral Sciences 91(2013), Pages 28-35.

Ahmad Zamil Zakaria, Ismail Hafiz Salleh, Mohd Sabrizaa Abd Rashid (2014). Identity of Malay Garden Design to be Promoted as the Cultural Tourism Product in Malaysia, Procedia - Social and Behavioral Sciences 153 (2014), Pages 298-307.

Ahmad Zamil Zakaria, Mohd Sabrizaa Abd Rashid, Syazwani Ahmad (2015). The Perak Malay Landscape Furniture Design: An Overview, i-CADER2015.

Ariffin, M.N dan Talib, A. (2005). Perak Malay (KUTAI) Architecture: A Methodological Approach in Extensive Survey and Analysis, UiTM, Shah Alam.

Cultural Landscapes, UNESCO retrieved on 20 December 2014 http://whc.unesco.org/en/culturallandscape/\#1

Gray, C. \& Malins, J. (2004). Visualizing Research: A Guide to the Research Process in Art and Design, Ashgate Publishing Limited, UK.

Haza Hanurhaza Md Jani, Mohd Ramzi Mohd Hussain (2014). Reclaiming the Loss of the Minangkabau Cultural Landscape in Negeri Sembilan, Procedia - Social and Behavioral Sciences 153 (2014), Pages 317 - 329.

Norhasandi Mat (2010). Ciri-ciri Fizikal Ruang Dalaman Rumah Melayu: Kajian Kes Rumah Bumbung Melayu Perak, PhD Thesis (Unpublished), Universiti Sains Malaysia.

Mitchell W. J. T. (2002). Landscape And Power, Second Edition, University Of Chicago Press.

Yuan, L. J. (1991). The Malay House: Rediscovering Malaysia's Indigenous Shelter System, Institut Masyarakat, Malaysia. 